\title{
The effect of age, sex and a firm-textured surface on postural control
}

\author{
Francesco Palazzo ${ }^{1}\left[\right.$ - Alessandra Nardi ${ }^{2} \cdot$ Niloofar Lamouchideli $^{1} \cdot$ Alfio Caronti $^{1} \cdot$ Anas Alashram $^{3} \oplus$. \\ Elvira Padua ${ }^{1,4}\left(\right.$ D $\cdot$ Giuseppe Annino $0^{1,4,5}$
}

Received: 4 April 2020 / Accepted: 13 February 2021 / Published online: 14 May 2021

(c) The Author(s) 2021

\begin{abstract}
In previous studies, the influence of plantar sensation has been examined using various textured surfaces with different stiffness materials to assess static balance. This study investigated the effects of a Firm Textured Surface (FTS) along with age and sex-related influences on postural control under different visual conditions. Forty subjects ( 20 elderly, 10 males, mean age 68.30, 10 females, mean age 68.00, and 20 young people, 10 males, mean age 25.45, 10 females, mean age 27.30) participated in this study maintained a quiet standing on FTS, foam and firm surfaces with eyes open and closed. The center of pressure displacement $\left(\mathrm{CoP}_{\mathrm{DISP}}\right)$, CoP velocity $\left(\mathrm{CoP}_{\mathrm{VEL}}\right)$, and sway velocity of the $\mathrm{CoP}$ in anteroposterior $(\mathrm{AP})$ and mediolateral (ML) direction $\left(\mathrm{V}_{\mathrm{A} / \mathrm{P}}\right.$ and $\left.\mathrm{V}_{\mathrm{M} / \mathrm{L}}\right)$ were measured. FTS was associated with lower postural sway measures in both the groups with eyes open and closed. However, the foam surface showed the worst results in all postural parameters under all experimental conditions. Separate four-way ANOVAs were applied to each dependent variable. The main effects of surface $(p<0.0001)$, vision $(p<0.0001)$ and age $\left(p<0.0001\right.$ for $\mathrm{CoP}_{\mathrm{DISP}}, \mathrm{CoP}_{\mathrm{VEL}}$ and $\mathrm{V}_{\mathrm{A} / \mathrm{P}} ; p=0.0003$ for $\left.\mathrm{V}_{\mathrm{M} / \mathrm{L}}\right)$ were significant in each of the four fitted models. Sex was never significant, either as a main effect or an interaction with other experimental factors. Eyes open were able to reduce the negative effects of the foam surfaces but without vision the proprioceptive sensory system cues of the body state become more important for maintaining balance. A good stimulation with rigid texture should be considered as relief to reduce the physiological-related decline of afferent information with age.
\end{abstract}

Keywords Plantar mechanoreceptors $\cdot$ Balance $\cdot$ Texture $\cdot$ Postural control $\cdot$ Age-related $\cdot$ Sex-related $\cdot$ Elderly

\section{Introduction}

Communicated by Winston D Byblow.

Francesco Palazzo

doc.francescopalazzo@gmail.com

1 School of Human Movement Science, Faculty of Medicine and Surgery, University of Rome "Tor Vergata", Via Giovanna Garzoni 39, 00133 Rome, CAP, Italy

2 Department of Mathematics, University of Rome "Tor Vergata", Rome, Italy

3 PhD School of Neuroscience, Faculty of Medicine and Surgery, University of Rome "Tor Vergata", Rome, Italy

4 Department of Human Sciences and Promotion of the Quality of Life, San Raffaele Roma Open University, Rome, Italy

5 Department of Medicine Systems, University of Rome “"Tor Vergata', Rome, Italy
The task of maintaining upright standing posture requires information from vision, the vestibular system and plantar tactile sensory inputs (Winter 1995; Mesquita et al. 2015). In previous research has been reported that the efficiency of postural control system depends mostly on the afferent activity from plantar cutaneous mechanoreceptors (Kavounoudias et al. 1998; Nurse and Nigg 2001b; Meyer et al. 2004; Zehr et al. 2014) located in the glabrous skin of human foot sole that is activated only in the presence of pressure, load, vibration (Priplata et al. 2003; Patel et al. 2011; Strzalkowski et al. 2017) and skin stretch sensory stimuli (Kennedy and Inglis 2002). Loss of just one of the three sensory systems can cause deterioration in postural stability. Indeed, vestibular dysfunction and/or lack of vision (Magnusson et al. 1990) cause body sway which increases with age. In this contest, plantar mechanoreceptors play an important role in body balance (Annino et al. 2015; Palazzo et al. 2015). In fact, it has been shown that reducing information from receptors 
located in skin through cooling foot sole (Nurse and Nigg 2001b), anesthesia (Meyer et al. 2004), ischemia conditions (Horak et al. 1990) and/or eliminating sensory information (Nejc et al. 2010) is associated with an increase in postural sway under perturbed postural responses. Controversy, stimulation of foot sole (Qiu et al. 2012; Wang et al. 2016) could lead to an improvement of balance (Hlavackova and Vuillerme 2012) through the modulation of load of lower limbs and the positioning of feet (Zehr et al. 2014).

Moreover, people over 60 years of age have more difficulties in maintaining upright posture due to their marked functional decline (Prieto et al. 1996; Kitabayashi et al. 2011) that can be related to the nervous system, muscles, joints or other causes (Prieto et al. 1996). Reciprocal relation between vision and mechanoreceptors is considered a critical factor that deteriorates progressively over years (Lord et al. 1991; Fitzpatrick and McCloskey 1994; Lord and Ward 1994). These sensory deficits of lower limb somatosensation can lead to an increase risk of falls (Tinetti et al. 1988; Shumway-Cook et al. 1997). To examine balance control, researchers have examined various features of postural response with different support surfaces positioned underneath foot (Chiang and Wu 1997; Blackburn et al. 2003; Jeka et al. 2004; Vrancken et al. 2005; Fransson et al. 2007; Patel et al. 2008). When standing on a foam surface, information from the cutaneous mechanoreceptors of sole of foot is less reliable (Chiang and Wu 1997; Perry et al. 2000), changing the patterns from receptors, increasing postural sway and changing standing strategy (Nurse and Nigg 2001a; Fransson et al. 2007). In addition, both young and elderly subjects showed differences in postural control, especially under altered sensory conditions such as altered vision (eyes closed) and surface (a soft contact surface). Instead, it would appear that this gap is reduced due to a compensation from remaining sensory sources, even if only one of sensory inputs was excluded or interrupted (Teasdale et al. 1991). However, standing on a textured surface resulting in an improvement of the Center of Pressure (CoP) displacement, which represents the position of the vertical ground reaction forces (Mancini and Horak 2010), CoP velocity mediolateral range (Corbin et al. 2007; Palluel et al. 2008; Hatton et al. 2011; Li et al. 2019) and a decreased co-contraction of agonist and antagonist muscles (Nurse and Nigg 2001b). Several studies have suggested a positive relationship between balance/postural regulation, and somatosensory feedback provided by the use of textured (Hlavackova and Vuillerme 2012; Losa Iglesias et al. 2012), especially in eyes-closed condition (Corbin et al. 2007; Qiu et al. 2012; Kenny et al. 2019a) while others have not found any effects with eyes open (Corbin et al. 2007; Hatton et al. 2009). Controversy, other authors demonstrates that textured surfaces have not always improved postural control (Wilson et al. 2008; Hatton et al. 2012; Qu 2015). In this context, an important variable of textured surfaces or insoles could be related to material stiffness. Some studies found improvements in postural control during static balance using soft textured insoles made in Evalite Pyramid EVA (Kenny et al. 2019b) or rigid textured surface made from plastic floor matting material (Corbin et al. 2007; Annino et al. 2015; Vieira et al. 2017) in healthy young subjects. Other studies used soft (Hatton et al. 2011; de Morais Barbosa et al. 2018), semi-rigid (Palluel et al. 2008), and rigid materials (Palazzo et al. 2015; Annino et al. 2018) to investigate postural stability in elderly people finding different results about analyzed postural parameters. Palluel et al. $(2008,2009)$ investigated the effects of sandals equipped with spike insoles, finding no immediate effects, but an improvement of postural control after 5 min standing or walking in elderly and young adults. Differently, (Qiu et al. 2012) investigated different stiffness materials, finding a significant and progressive decrease in postural sway from barefoot with the use of hard and soft textured insole surfaces in older group and small improvements in younger participants when standing on textured surfaces. In addition to textured materials, some authors have used different additional thicknesses to improve sensory information from sole of foot (Janin and Toussaint 2005; Janin and Dupui 2009; Viseux et al. 2018), suggesting that depression of material stimulated the units of cutaneous mechanoreceptors of type I and II (Forth and Layne 2007, 2008) thereby improving neuromuscular activity (Viseux et al. 2019). Furthermore, some authors investigated sex, and age effects on postural stability on non-stimulating surfaces, finding conflicting results. Some studies found sex-related differences (Overstall et al. 1978; Kim et al. 2010) differently to other studies (Røgind et al. 2003; Demura et al. 2008) without clarifying whether sex and aging processes related to it affect postural control ability. Considering that most of studies investigated soft and semi-rigid textured surface into age-related effects on balance, the aim of this study was to analyze the effects of Firm Textured Surface (FTS), with no deformable spikes along with age and sex-related influences on postural control in various vision conditions comparing postural sway measures (Center of Pressure displacement, Center of Pressure velocity, and sway velocity in anterior-posterior and mediolateral directions).

\section{Materials and methods}

\section{Participants}

Data from two groups of participants were used in this study. The first group consisted of 20 healthy older people $(10$ males, mean age $68.60 \pm 4.74$ years, mean height $173.30 \pm 5.91 \mathrm{~cm}$, mean weight $82.60 \pm 14.94 \mathrm{~kg}$; and 10 females, mean age $68.00 \pm 5.17$ years, mean height 
$160.78 \pm 5.49 \mathrm{~cm}$, mean weight $68.33 \pm 5.41 \mathrm{~kg}$ ). The second group included 20 healthy young subjects (10 males, mean age $23.60 \pm 2.46$ years, mean height $174.10 \pm 6.77 \mathrm{~cm}$, mean weight $66.80 \pm 6.44 \mathrm{~kg}$; and 10 females, mean age $27.30 \pm 3.47$ years, mean height $160.10 \pm 4.79 \mathrm{~cm}$, mean weight $55.90 \pm 7.52 \mathrm{~kg}$ ).

All subjects had normal vision or corrected to normal with glasses, and reported no history of balance deficits, neurologic disorders, or musculoskeletal injury, and signed the informed consent form granted by the Institutional Review Ethics Board prior to the test. More precise information regarding the aims, benefits, and risks was provided to all the participants set by the Helsinki Declaration. All assessments were performed in a controlled laboratory environment for this study.

\section{Equipment}

The center of pressure displacement $\left(\mathrm{CoP}_{\text {DISP }}\right)$ was measured using a custom-built force platform with six uniaxial load cells of which three were arranged on the left side and another three on the right side (Posture2000-S.A.I.R. s.r.l., Santa Rufina di Cittaducale, Rieti, Italy), and using a PC, which was connected through an amplifier. Signals from the force platform were sampled at $1 \mathrm{kHz}$ amplified, converting analog signals to digital form. Data were smoothed using low-pass digital filters with a cut-off frequency of $10 \mathrm{~Hz}$. All variables were calculated with Posture2000 software. For each foot, ground reaction forces and $\mathrm{CoP}$ measures were recorded from the force platform. Both $\mathrm{A} / \mathrm{P}$ and $\mathrm{M} / \mathrm{L} \mathrm{CoPs}$ were recorded: the left $\mathrm{CoP}(\mathrm{CoP} l)$ and right $\mathrm{CoP}(\mathrm{CoP} r)$ plus the $\mathrm{CoP}_{\text {DISP }}$ as calculated from a weighted average of the two CoPs (Winter et al. 1996); $\mathrm{CoP}_{\mathrm{DISP}}=\mathrm{CoP} l * \mathrm{R} v l /$ $(\mathrm{R} v l+\mathrm{R} v r)+\mathrm{CoPr} * \mathrm{R} v r /(\mathrm{R} v l+\mathrm{R} v r)$, where $\mathrm{R} v l$ and $\mathrm{R} v r$ are the left and right vertical reaction force, respectively. The $\mathrm{CoP}$ velocity $\left(\mathrm{CoP}_{\mathrm{VEL}}\right)$ and sway velocity of $\mathrm{CoP}$ in $\mathrm{A} / \mathrm{P}$ and $\mathrm{M} / \mathrm{L}$ direction $\left(\mathrm{V}_{\mathrm{A} / \mathrm{P}}\right.$ and $\left.\mathrm{V}_{\mathrm{M} / \mathrm{L}}\right)$ were measured. Each $\mathrm{CoP}_{\mathrm{DISP}}, \mathrm{CoP}_{\mathrm{VEL}}, \mathrm{V}_{\mathrm{A} / \mathrm{P}}$ and $\mathrm{V}_{\mathrm{M} / \mathrm{L}}$ measurements were performed under the same condition.

\section{Experimental procedures}

The test battery consisted of a bipedal stance on the three different surfaces (firm-textured surface, besides, the foam and firm surface as control surfaces) with eyes open (EO) and eyes closed (EC). Each test duration was $20 \mathrm{~s}$ (Le Clair and Riach 1996) to avoid fatigue for a total of 6 tests for each subject. Each registration was begun shortly after the operator's assistance asked to remain motionless. Each $\mathrm{CoP}_{\mathrm{DISP}}, \mathrm{CoP}_{\mathrm{VEL}}, \mathrm{V}_{\mathrm{A} / \mathrm{P}}$ and $\mathrm{V}_{\mathrm{M} / \mathrm{L}}$ were analyzed for all $20 \mathrm{~s}$. There were $120 \mathrm{~s}$ of rest time between the different surface tests. The surfaces were used for each participant in a randomized order. Each participant performed the test battery in eyes-open condition and the testing location was free of visual and acoustic distraction. After the eyes-open trial, the subject sat on a chair for approximately two minutes before the procedure was repeated with eyes closed.

The thickness of the foam mat was $7 \mathrm{~mm}$. In the measurement setup, the foam was placed on top of the force platform without contacting surrounding grounds. The firm-textured disc (Footon-Servetto, Milan, Italy) was $33 \mathrm{~cm}$ in diameter with many semi-circular protrusions spaced $17 \mathrm{~mm}$ apart, height of $3.5 \mathrm{~mm}$, and width of $2 \mathrm{~mm}$ (Fig. 1).

Under the different surface conditions, all subjects stood barefoot with the full length of both feet in contact with the force platform with their arms relaxed along their side to avoid inappropriate results, and they were also asked to sway as little as possible. Both feet were abducted at $30^{\circ}$ and the heels were spaced $9 \mathrm{~cm}$ apart (Palazzo et al. 2019). Participants were not familiarized with the surfaces before the test.

\section{Statistical analysis}

As the first step in the statistical analysis, a marginal univariate analysis of measured data was performed to determine significant differences among the three considered surfaces in the different conditions. Continuous variables were described by mean and standard deviation. Box and Whisker plots were created to show the distribution of responses among the different surfaces. The Kolmogorov-Smirnov test was used to validate the assumption of normality. Since no significant departures from normality were detected, at multivariable analysis four-way Analysis of Variance (ANOVA) was used to model observed responses in terms of the main effects and possible twoway interactions. Data analysis was limited to two-way interactions to guarantee consistency between the number of parameters to be estimated and the sample size. Four

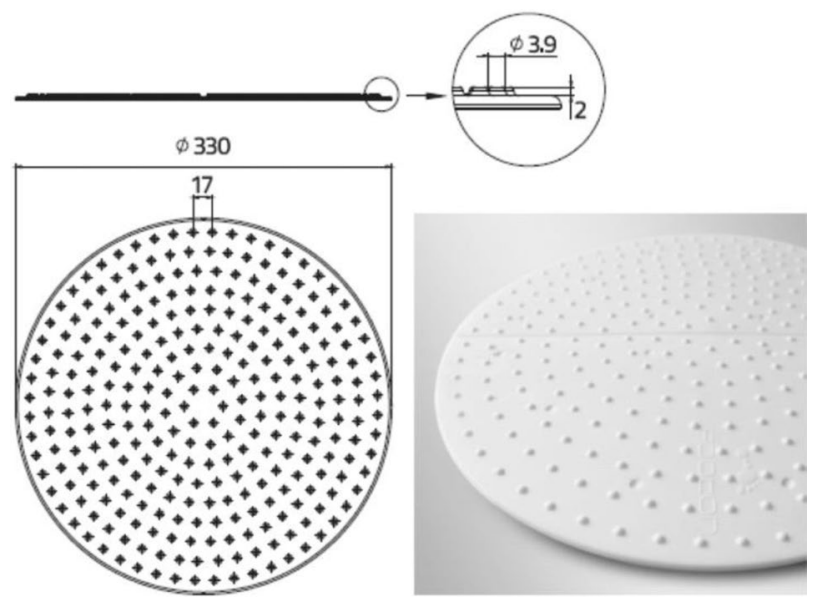

Fig. 1 Schematic representation of Firm Textured Surface. Measures are expressed in millimeters 


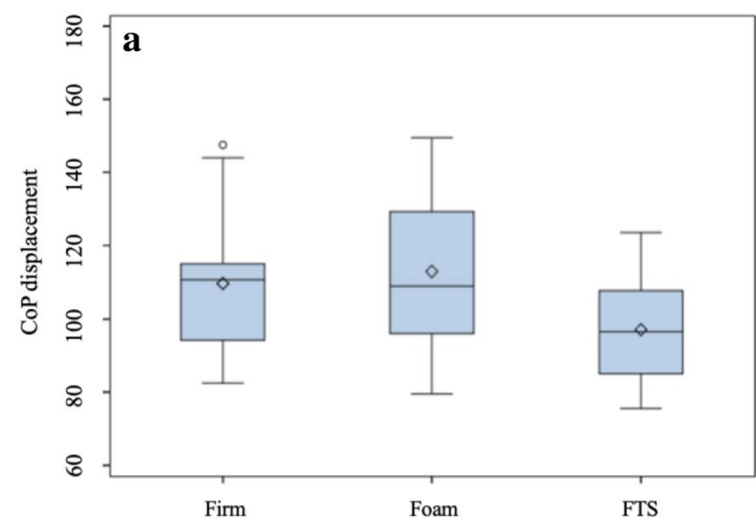

Fig. 2 Distribution of CoP displacement for different surfaces with no vision condition. The bottom and top edges of the box are located at the 25th and 75th percentiles of the sample and, within the box, the median is displayed as a line and the mean as a diamond, vertical

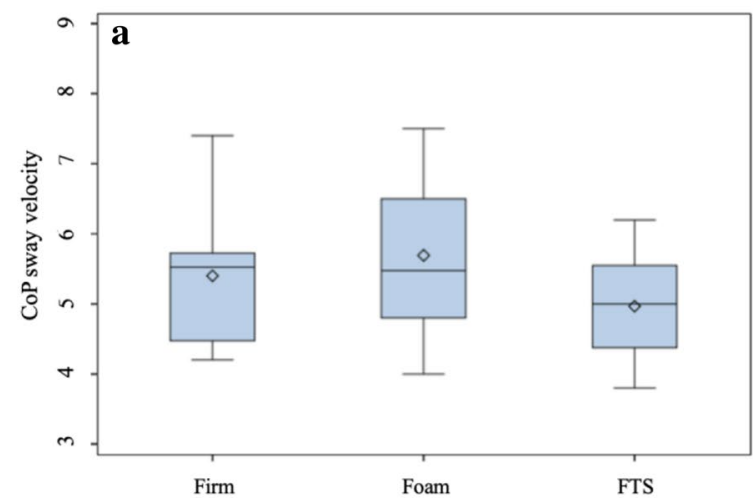

Fig. 3 Distribution of CoP sway velocity for different surfaces with no vision condition. The bottom and top edges of the box are located at the 25th and 75th percentiles of the sample and, within the box, the median is displayed as a line and the mean as a diamond, vertical

different separate models were fitted, assuming as response variables $\mathrm{CoP}_{\mathrm{DISP}}, \mathrm{CoP}_{\mathrm{VEL}}, \mathrm{V}_{\mathrm{A} / \mathrm{P}}$, and $\mathrm{V}_{\mathrm{M} / \mathrm{L}}$, respectively. In each model, Surface, Vision, Age and Gender were assumed as independent variables; we considered 3 levels for Surface $\times 2$ levels for Vision $\times 2$ levels for Age $\times 2$ levels for Sex. The F-test was used to detect significant effects, assuming $\alpha=0.05$. The correlation among measurements from the same participant was modeled by introducing a variance and covariance matrix whose structure was unspecified completely. For significant effects, estimated differences were reported and evaluated using the $t$-test. The Tukey-Kramer adjustment for multiplicity was used. All analyses were undertaken using SAS version 9.4 (SAS Institute, Cary NC).

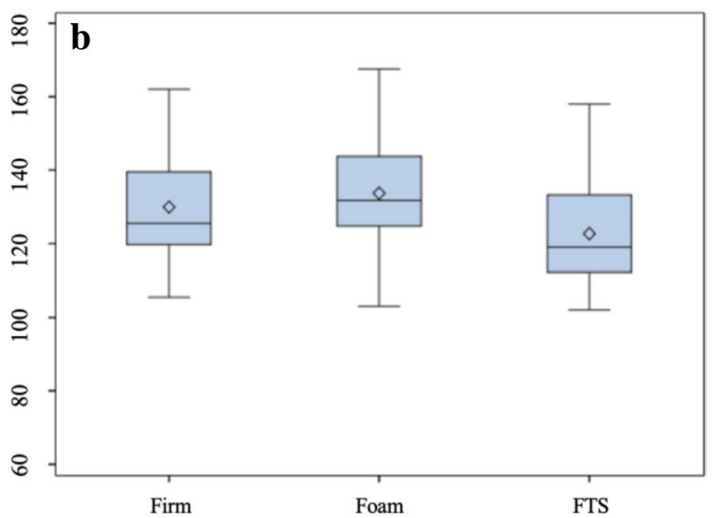

lines end at the largest and the smallest observed value unless outlying observations (circles) are present. (a) Young individuals, (b) Elder individuals

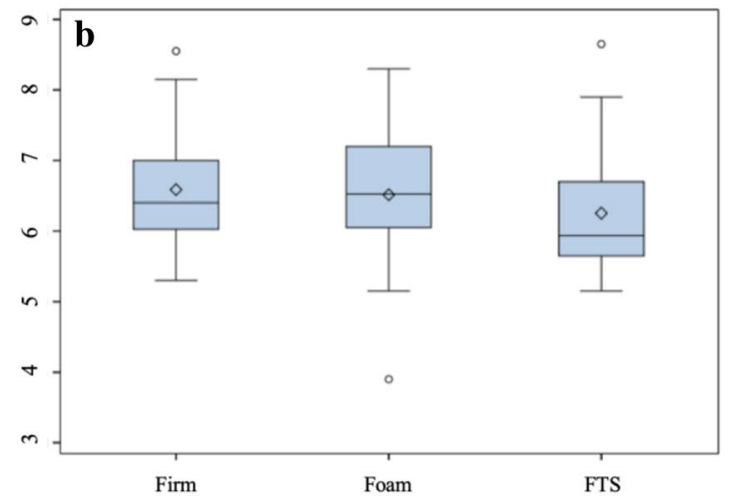

lines end at the largest and the smallest observed value unless outlying observations (circles) are present. (a) Young individuals, (b) Elder individuals

\section{Results}

The first descriptive analysis (Table 1) showed that the elderly was significantly unstable in all the analyzed postural parameters than the young people. The differences were more pronounced in the eyes-closed condition. In the eyes-open condition, the gap between the young and old individuals was reduced when standing on the foam surface. In the comparison among the different surfaces, FTS was associated with lower postural sway measures in both the groups with open and closed eyes (Figs. 2 and 3). On the contrary, the foam showed the worst results in all postural parameters during all the experimental conditions. 
Table 1 Postural parameters mean (mm) and standard deviation (SD)

\begin{tabular}{|c|c|c|c|c|c|c|}
\hline & \multicolumn{3}{|l|}{ Eyes open } & \multicolumn{3}{|l|}{ Eyes closed } \\
\hline & Firm & Foam & FTS & Firm & Foam & FTS \\
\hline \multicolumn{7}{|c|}{ CoPDISP (mm) } \\
\hline Young & $98.50 \pm 14.29$ & $103.70 \pm 15.03$ & $92.48 \pm 15.64$ & $109.70 \pm 19.21$ & $112.93 \pm 19.77$ & $97.08 \pm 15.12$ \\
\hline Elderly & $110.70 \pm 15.15$ & $113.00 \pm 16.34$ & $104.40 \pm 14.27$ & $129.90 \pm 15.94$ & $133.70 \pm 16.56$ & $122.70 \pm 15.84$ \\
\hline \multicolumn{7}{|c|}{ CoPVEL (mm/s) } \\
\hline Young & $4.86 \pm 0.64$ & $5.16 \pm 0.74$ & $4.66 \pm 0.79$ & $5.40 \pm 0.95$ & $5.69 \pm 1.03$ & $4.97 \pm 0.73$ \\
\hline Elderly & $5.55 \pm 0.70$ & $5.67 \pm 0.80$ & $5.26 \pm 0.68$ & $6.59 \pm 0.89$ & $6.52 \pm 1.01$ & $6.25 \pm 0.95$ \\
\hline \multicolumn{7}{|c|}{$\mathrm{VA} / \mathrm{P}(\mathrm{mm} / \mathrm{s})$} \\
\hline Young & $3.70 \pm 0.61$ & $4.05 \pm 0.57$ & $3.64 \pm 0.61$ & $4.30 \pm 0.72$ & $4.35 \pm 0.75$ & $3.87 \pm 0.63$ \\
\hline Elderly & $4.23 \pm 0.72$ & $4.40 \pm 0.62$ & $4.17 \pm 0.66$ & $5.19 \pm 0.80$ & $5.40 \pm 0.82$ & $4.99 \pm 0.82$ \\
\hline \multicolumn{7}{|c|}{$\mathrm{VM} / \mathrm{L}(\mathrm{mm} / \mathrm{s})$} \\
\hline Young & $2.52 \pm 0.58$ & $2.93 \pm 0.74$ & $2.43 \pm 0.73$ & $2.91 \pm 0.71$ & $3.19 \pm 0.76$ & $2.65 \pm 0.63$ \\
\hline Elderly & $3.21 \pm 0.38$ & $3.31 \pm 0.41$ & $3.07 \pm 0.39$ & $3.63 \pm 0.54$ & $3.69 \pm 0.54$ & $3.44 \pm 0.51$ \\
\hline
\end{tabular}

The table shows the analysis of postural parameters for CoPDISP $=$ Center of Pressure displacement, CoPVEL $=$ sway velocity of Center of Pressure, VA/P = anteroposterior sway velocity, $\mathrm{VM} / \mathrm{L}=$ mediolateral sway velocity in both group (elderly and young) on three surfaces Firm, Foam and Firm textured Surface (FTS)

Separate four-way ANOVAs were applied to each dependent variable, and the type of surface, vision, age, and gender were identified as the experimental factors (Table 2).

The main effect of the surface was significant in all the four fitted models $(p<0.0001)$ : the observed $\mathrm{F}$ values were $41.89,28.40,17.63$ and 26.46 for $\mathrm{CoP}_{\mathrm{DISP}}, \mathrm{CoP}_{\mathrm{VEL}}, \mathrm{V}_{\mathrm{A} / \mathrm{P}}$ and $\mathrm{V}_{\mathrm{M} / \mathrm{L} \text {, respectively. }}$

Vision showed a significant main effect on each response variable $(p<0.0001)$ : the observed $\mathrm{F}$ values were 83.99, 68.23, 68.06 and 37.02 for $\operatorname{CoP}_{\text {DISP, }} \operatorname{CoP}_{\mathrm{VEL}}, \mathrm{V}_{\mathrm{A} / \mathrm{P}}$ and $\mathrm{V}_{\mathrm{M} / \mathrm{L} \text {, }}$ respectively.

The main effect of age was significant in each of the four fitted models $\left(p<0.0001\right.$ for $\mathrm{CoP}_{\mathrm{DISP}}, \mathrm{CoP}_{\mathrm{VEL}}$ and $\mathrm{V}_{\mathrm{A} / \mathrm{P}}$; $p=0.0003$ for $\mathrm{V}_{\mathrm{M} / \mathrm{L}}$ ): the observed $\mathrm{F}$ values were 21.61, 19.95, 16.26 and 18.32 for $\mathrm{CoP}_{\mathrm{DISP}}, \mathrm{CoP}_{\mathrm{VEL}}, \mathrm{V}_{\mathrm{A} / \mathrm{P}}$ and $\mathrm{V}_{\mathrm{M} / \mathrm{L} \text {, }}$ respectively.

Nevertheless, the gender was never significant, either as a main effect or an interaction with other experimental factors.

When $\mathrm{CoP}_{\mathrm{DISP}}$ was the response variable, the main effects of the surface were shown in Table 3. In details, FTS was more stable in comparison to the foam (estimated difference (e.d.) $-11.53 \mathrm{~mm}$, standard error (s.e.) 1.26) and the firm surfaces (e.d. $-8.10 \mathrm{~mm}$, s.e. 1.67), while no significant difference was detected between the firm and foam surfaces. Moreover, in the elderly group the instability was observed under both visual conditions (e.d. $+13.11 \mathrm{~mm}$, s.e. 4.10 ), especially during eyes-closed condition (e.d. $+25.40 \mathrm{~mm}$, s.e. 4.66).

When $\mathrm{CoP}_{\mathrm{VEL}}$ were the response variable, the FTS was confirmed as the most effective surface in reducing instability, the estimated difference was $-0.48 \mathrm{~mm} / \mathrm{s}$, (s.e.
0.06 ) and $-0.31 \mathrm{~mm} / \mathrm{s}$ (s.e. 0.08 ) compared to the foam and the firm surface, respectively (Table 3 ). As already observed in $\mathrm{CoP}_{\mathrm{DISP}}$, the gap between elder and young people was more evident when subjects closed their eyes.

In addition, when $\mathrm{CoP}_{\mathrm{DISP}}$ and $\mathrm{CoP}_{\mathrm{VEL}}$ were the response variable, we detected a significant interaction between vision and age (Table 3 ).

When $\mathrm{V}_{\mathrm{A} / \mathrm{P}}$ was modeled, the significant interaction of surface $\mathrm{x}$ vision and vision $\times$ age were reported in Table 3 . In detail, the difference between FTS and the foam was significantly higher in the eyes-closed condition than the eyes-open condition (e.d. $-0.45 \mathrm{~mm} / \mathrm{s}$, s.e. 0.08 vs e.d. $-0.32 \mathrm{~mm} / \mathrm{s}$, s.e. 0.07$)$. Similarly, the data showed that the difference between FTS and the firm was negligible with eyes open, while becoming significant with eyes closed (e.d. $-0.32 \mathrm{~mm} / \mathrm{s}$, s.e. 0.09 ). The difference between the firm and the foam was only significant in the eyes-open condition (e.d. $0.26 \mathrm{~mm} / \mathrm{s}$, s.e. 0.08 ). No significant difference was detected between the elderly and the young with eyes open, while this difference was significant in the eyes-closed condition (e.d. $1.06 \mathrm{~mm} / \mathrm{s}$, s.e. 0.22 ).

In $\mathrm{V}_{\mathrm{M} / \mathrm{L}}$ analysis (Table 2), a single significant interaction Surface $\times$ Age was detected. In Table 3, it is possible to note a constant worsening effect of the eyes-closed condition (e.d. $-0.34 \mathrm{~mm} / \mathrm{s}$, s.e. 0.06 ). The difference between FTS and the foam was significant in both the elderly and young subjects, but the stabilizing effect was higher at the end (e.d. $-0.26 \mathrm{~mm} / \mathrm{s}$, s.e. $0.07 v s$ e.d. $-0.51 \mathrm{~mm} / \mathrm{s}$, s.e. 0.07). FTS and the firm showed similar results with eyes open and closed. 
Table 2 Measurement of postural control under different sensory conditions

\begin{tabular}{|c|c|c|}
\hline \multirow[t]{2}{*}{ Effects } & \multicolumn{2}{|c|}{ CoPDISP } \\
\hline & $F$ value & $p$-value \\
\hline Surface & 41.89 & $<0.0001$ \\
\hline Vision & 83.99 & $<0.0001$ \\
\hline Age & 21.61 & $<0.0001$ \\
\hline Vision $\times$ Age & 17.90 & 0.0001 \\
\hline \multirow[t]{2}{*}{ Effects } & \multicolumn{2}{|l|}{ CoPVEL } \\
\hline & $F$ value & $p$-value \\
\hline Surface & 28.40 & $<0.0001$ \\
\hline Vision & 68.23 & $<0.0001$ \\
\hline Age & 19.95 & $<0.0001$ \\
\hline Vision $\times$ Age & 10.66 & 0.0023 \\
\hline \multirow[t]{2}{*}{ Effects } & \multicolumn{2}{|l|}{$\mathrm{VA} / \mathrm{P}$} \\
\hline & $F$ value & $p$-value \\
\hline Surface & 17.63 & $<0.0001$ \\
\hline Vision & 68.06 & $<0.0001$ \\
\hline Age & 16.26 & 0.0003 \\
\hline Surface $\times$ Vision & 4.46 & 0.0181 \\
\hline Vision $\times$ Age & 18.82 & 0.0001 \\
\hline \multirow[t]{2}{*}{ Effects } & \multicolumn{2}{|l|}{$\mathrm{VM} / \mathrm{L}$} \\
\hline & $F$ value & $p$-value \\
\hline Surface & 26.46 & $<0.0001$ \\
\hline Vision & 37.02 & $<0.0001$ \\
\hline Age & 18.32 & 0.0001 \\
\hline Surface $\times$ Age & 3.57 & 0.0380 \\
\hline
\end{tabular}

The table shows the significant effects on CoPDISP, CoPVEL, VA/P and VM/L of surfaces (Firm as control surfaces, Foam and FTS), vision (open and closed eyes), age (young and elderly) and the significant interactions. $P<0.05$

\section{Discussion}

According to several investigations that demonstrated how a foam surface had poor performances resulting in the worst surface material for upright posture in elderly and young people (Chiang and Wu 1997; Perry et al. 2000; Nurse et al. 2005; Fransson et al. 2007), the data of this study suggest that FTS with no deformable spikes influence postural control system through tactile sensory inputs of the plantar foot, in both the elderly and the young people (Orth et al. 2013). These results seem to confirm previous evidence, despite using different surface materials (Palluel et al. 2008, 2009; Qiu et al. 2012). The characteristics of materials such as shape, contour and hardness could affect the degree of deformation of skin receptors (Orth et al. 2013) and consequently affect their stimulation to some degree (Hatton et al. 2011; Qiu et al. 2012).
Tests carried out by various studies have shown that height, texture, and spacing between spikes stimulate differently plantar surface, thus justifying controversial results found by various authors (Viseux et al. 2019). In a study, three textured surfaces with different spacing between protrusions (20-15-10 $\mathrm{mm}$ ) have been investigated, finding an improvement in postural stability as distance between protrusions decreased, both with eyes open and closed (Watanabe et al. 1981). The height $(3.5 \mathrm{~mm})$ and distance between the spikes $(17 \mathrm{~mm})$ of the FTS used in this study could be optimal for achieving better plantar stimulation in both the young and the elderly people. Presumably, there was greater sensory discrimination by plantar mechanoreceptors and consequently more efficient neuromuscular activity (Forth and Layne 2007, 2008) which could justify the more consistent results compared to other studies. In fact, some authors have stated that if plantar skin is adequately stimulated, postural control improves probably through more afferent 
Table 3 Estimated differences at multivariable analysis

\begin{tabular}{|c|c|c|c|}
\hline \multirow[t]{2}{*}{ Effect } & \multicolumn{3}{|l|}{ CoPDISP } \\
\hline & Estimated difference (mm) & s.e & $p$-value \\
\hline \multicolumn{4}{|l|}{ Surface } \\
\hline FTS - Foam & -11.53 & 1.26 & $<0.0001 *$ \\
\hline FTS - Firm & -8.10 & 1.67 & $<0.0001 *$ \\
\hline Firm—Foam & 3.44 & 1.46 & 0.0596 \\
\hline \multicolumn{4}{|l|}{ Vision $\times$ Age } \\
\hline OE Elderly-Young & 13.11 & 4.10 & $<0.0142 *$ \\
\hline \multirow[t]{3}{*}{ CE Elderly_Young } & 25.40 & 4.66 & $<0.0001 *$ \\
\hline & \multicolumn{3}{|l|}{ CoPVEL } \\
\hline & Estimated difference $(\mathrm{mm} / \mathrm{s})$ & s.e & $p$-value \\
\hline \multicolumn{4}{|l|}{ Effect } \\
\hline \multicolumn{4}{|l|}{ Surface } \\
\hline FTS - Foam & -0.48 & 0.06 & $<0.0001^{*}$ \\
\hline FTS - Firm & -0.31 & 0.08 & $0.0010^{*}$ \\
\hline Firm—Foam & 0.18 & 0.07 & $0.0298 *$ \\
\hline \multicolumn{4}{|l|}{ Vision $\times$ Age } \\
\hline OE Elderly_Young & 0.65 & 0.20 & $<0.0132 *$ \\
\hline \multirow[t]{2}{*}{ CE Elderly_Young } & 1.20 & 0.24 & $<0.0001^{*}$ \\
\hline & \multicolumn{3}{|l|}{ VA/P } \\
\hline Effect & Estimated difference $(\mathrm{mm} / \mathrm{s})$ & s.e & $p$-value \\
\hline \multicolumn{4}{|l|}{ Surface $\mathrm{x}$ Vision } \\
\hline OE FTS - Foam & -0.32 & 0.07 & $0.0014 *$ \\
\hline OE FTS - Firm & -0.06 & 0.07 & 0.9584 \\
\hline OE Firm-Foam & 0.26 & 0.08 & $0.0300^{*}$ \\
\hline CE FTS - Foam & -0.45 & 0.08 & $<0.0001 *$ \\
\hline CE FTS - Firm & -0.32 & 0.09 & $0.0095 *$ \\
\hline CE Firm—Foam & 0.13 & 0.09 & 0.6604 \\
\hline \multicolumn{4}{|l|}{ Vision $\mathrm{x}$ Age } \\
\hline OE Elderly_Young & 0.42 & 0.18 & 0.1006 \\
\hline CE Elderly-Young & 1.06 & 0.22 & $0.0001 *$ \\
\hline \multirow[t]{2}{*}{ Effect } & \multicolumn{3}{|l|}{ VM/L } \\
\hline & Estimated difference $(\mathrm{mm} / \mathrm{s})$ & s.e & $p$-value \\
\hline \multicolumn{4}{|l|}{ Vision } \\
\hline $\mathrm{OE}-\mathrm{CE}$ & -0.34 & 0.06 & $<0.0001^{*}$ \\
\hline \multicolumn{4}{|l|}{ Surface $\times$ Age } \\
\hline Young FTS - Foam & -0.51 & 0.07 & $<0.0001^{*}$ \\
\hline Young FTS - Firm & -0.17 & 0.08 & 0.2671 \\
\hline Young Firm—Foam & 0.34 & 0.09 & $0.0041^{*}$ \\
\hline Elderly FTS - Foam & -0.26 & 0.07 & $0.0146^{*}$ \\
\hline Elderly FTS - Firm & -0.18 & 0.08 & 0.2247 \\
\hline Elderly Firm—Foam & 0.08 & 0.09 & 0.9440 \\
\hline
\end{tabular}

The table shows the differences of positive effects on CoP displacement, CoPVEL, VA/P and VM/L

$* P<0.05$ 
information from plantar mechanoreceptors to the Central Nervous System (Manjarrez et al. 2003; Menant et al. 2008; Viseux et al. 2018).

In addition, vision plays a crucial role in generating an internal model of body in space (Peterka 2002). In this study, the analyzed postural parameters increased significantly with eyes closed in comparison with eyes open, but according to Kenny et al. it was surprising that there was no significant interaction between surface and vision (Kenny et al. 2019b), except to $\mathrm{V}_{\mathrm{A} / \mathrm{P}}$. In fact, post-hoc analysis showed a significant reduction in $\mathrm{V}_{\mathrm{A} / \mathrm{P}}$ during static upright posture on FTS in comparison to the foam in the EO and EC conditions as shown in Table 3. On the other hand, in the comparison with the firm surface, a significant reduction was observed only with EC. These results may confirm hypothesis of previous studies about the beneficial effects of plantar sensory stimulation through a textured surface (Palazzo et al. 2014, 2019; Annino et al. 2015, 2018), especially in eyes-closed conditions (Qiu et al. 2012; Kenny et al. 2019b), and the negative effects of the foam surface on postural control (Teasdale et al. 1991).

The significant effects on $\mathrm{CoP}_{\mathrm{DISP}}, \mathrm{CoP}_{\mathrm{VEL}}, \mathrm{V}_{\mathrm{A} / \mathrm{P}}$, and $\mathrm{V}_{\mathrm{M} / \mathrm{L}}$ were also evident in the age analysis seem to confirm previous studies (Winter et al. 1996; Kitabayashi et al. 2011; Pasma et al. 2014) reporting a large body sway in elderly compared to young people due to a decrease in overall somatosensory function in over 60's (Magnusson et al. 1990; Collins et al. 1995; Demura et al. 2008).

The significant two-interaction Vision $\mathrm{x}$ Age for $\mathrm{CoP}_{\mathrm{DISP}}$, $\mathrm{CoP}_{\mathrm{VEL}}$, and $\mathrm{V}_{\mathrm{A} / \mathrm{P}}$, showing a larger gap between the elder and younger people, especially in the EC condition. Instead, the significant two-interaction Surface $\times$ Age in $V_{M / L}$ showed very poor performances on the foam surface, suggesting that FTS should be preferred especially in the elderly subjects. In line with the results of the present study, the velocity parameters in the ML direction were suggested to detect age-related differences in the permanent's quality balance (Raymakers et al. 2005; Pasma et al. 2014). Differently from young adults where $\mathrm{A} / \mathrm{P}$ movement plays a significant role (ankle strategy), in older adults, $\mathrm{M} / \mathrm{L}$ movement (hip strategy) is prevalently adopted (Jančová 2008; Hatton et al. 2011). Considering that $\mathrm{M} / \mathrm{L}$ balance control strategy, can cause accidents in falls or severe injury in elderly people (Eibling 2018), these results seem to intervene in this direction helping hip strategy. Differently from A/P direction where balance strategy is facilitated by the correction of stepping forward or backward (Winter et al. 1996), in M/L balance strategy unsupported lower limb is on opposite side of direction of fall and, in this case, it would be difficult to recover balance quickly (Rogers and Mille 2003). This improvement could be due both to stimulate tactile sensory inputs of the plantar foot by the semi-circular protrusions and a different multiple-link strategy between the surfaces. It is well know that four kinds of cutaneous mechanoreceptors that deliver important feedback about the environment and innervate glabrous skin (Patel et al. 2008): the rapidly adapting Meissner's corpuscle (MC) and Pacinian corpuscle (PC), the slowly adapting Merkel disk and Ruffini's ending (Patel et al. 2008). Each of these neuron types responds to cutaneous motion and deformation in a different way (Johnson 2001). Also, both Pacinian and Meissner's receptors have been associated with declines in touch thresholds. Especially the cutaneous slowly adapting type 1 (SA1) has proven to be the main responsible for shape and roughness perception by responding to a sustained skin deformation with a prolonged discharge. In fact, it has been demonstrated in previous studies that the perception of texture depends on the distributed statistical properties of a surface or material (Kenny et al. 2019a) and on a measure of the neural response SA1 which is extracted from the central neurons with simple excitatory and inhibitory subfields (Johnson 2001).

Also, this study did not show a significant difference between males and females in all the analyzed postural parameters agreeing to previous studies (Røgind et al. 2003; Demura et al. 2008). Nakamura et al. did not find a significant difference between genders in young subjects, but only in elderly subjects where males were more unstable than females, suggesting that the differences in height could explain the result being the tallest male (Nakamura et al. 2001). In our study, there were differences in average height between the males and females in the young and elderly groups and the analyzed data suggested that these differences did not influence postural stability. Instead, in a study by Overstall et al., males showed higher stability than females (Overstall et al. 1978). More in detail, Kim et al. showed a difference between sexes and age-related balance, especially in mediolateral direction (Kim et al. 2010). Despite the results of this study where postural control is not influenced by sex, further and depth investigation should be needed in future.

In conclusion, the most realistic hypothesis presently is that a textured firm surface improves postural control in the all groups (significant main effect of the surface) and as a result should be especially interesting in older subjects known to exhibit deficits in postural stability. A firmtextured surface stimulated better sensory plantar receptors in all the groups. The characteristics of the textured material, such as hardness, height, and spacing between the protrusions could be essential to achieve an optimal sensory stimulation and consequently improve better postural control. In addition, it is also presumable that the surface $x$ age interaction with a larger sample of elderly subjects and/or with more trials, could have reached significance. The difference between both groups on the foam surface is considerably less compared to the other surfaces. Further gait analysis with surface electromyography (EMGs) studies 
using non-deformable stimulating surface needed to observe the influence of plantar sensory inputs and joint strategies on neuromuscular control.

Funding Open access funding provided by Università degli Studi di Roma Tor Vergata within the CRUI-CARE Agreement. The authors have no source of funding or any potential conflicts of interest to disclose.

\section{Compliance with ethical standards}

Conflict of interest The authors certify that there is no conflict of interest with any financial organization regarding the material discussed in the manuscript.

Open Access This article is licensed under a Creative Commons Attribution 4.0 International License, which permits use, sharing, adaptation, distribution and reproduction in any medium or format, as long as you give appropriate credit to the original author(s) and the source, provide a link to the Creative Commons licence, and indicate if changes were made. The images or other third party material in this article are included in the article's Creative Commons licence, unless indicated otherwise in a credit line to the material. If material is not included in the article's Creative Commons licence and your intended use is not permitted by statutory regulation or exceeds the permitted use, you will need to obtain permission directly from the copyright holder. To view a copy of this licence, visit http://creativecommons.org/licenses/by/4.0/.

\section{References}

Annino G, Palazzo F, Lebone P et al (2015) The efficacy of plantar stimulation on human balance control. Somatosens Mot Res. https://doi.org/10.3109/08990220.2015.1054025

Annino G, Palazzo F, Alwardat MS, et al (2018) Effects of long-term stimulation of textured insoles on postural control in health elderly. J Sports Med Phys Fitness 58:377-384 https://doi.org/ 10.23736/S0022-4707.16.06705-0

Blackburn JT, Riemann BL, Myers JB, Lephart SM (2003) Kinematic analysis of the hip and trunk during bilateral stance on firm, foam, and multiaxial support surfaces. Clin Biomech 18:655-661. https://doi.org/10.1016/S0268-0033(03)00091-3

Chiang JH, Wu G (1997) The influence of foam surfaces on biomechanical variables contributing to postural control. Gait Posture 5:239-245. https://doi.org/10.1016/S0966-6362(96)01091-0

Collins JJ, De Luca CJ, Burrows A, Lipsitz LA (1995) Age-related changes in open-loop and closed-loop postural control mechanisms. Exp Brain Res 104:480-492. https://doi.org/10.1007/ BF00231982

Corbin DM, Hart JM, McKeon PO et al (2007) The effect of textured insoles on postural control in double and single limb stance. J Sport Rehabil 16:363-372. https://doi.org/10.1123/jsr.16.4.363

de Morais BC, Bértolo MB, Gaino JZ et al (2018) The effect of flat and textured insoles on the balance of primary care elderly people: A randomized controlled clinical trial. Clin Interv Aging 13:277284. https://doi.org/10.2147/CIA.S149038

Demura S-I, Kitabayashi T, Aoki H (2008) Body-sway characteristics during a static upright posture in the elderly. Geriatr Gerontol Int 8:188-197. https://doi.org/10.1111/j.1447-0594.2008.00469.x

Eibling D (2018) Balance disorders in older adults. Clin Geriatr Med 34:175-181. https://doi.org/10.1016/j.cger.2018.01.002
Fitzpatrick R, McCloskey DI (1994) Proprioceptive, visual and vestibular thresholds for the perception of sway during standing in humans. J Physiol 478:173-186. https://doi.org/10.1113/jphysiol. 1994.sp020240

Forth KE, Layne CS (2007) Background muscle activity enhances the neuromuscular response to mechanical foot stimulation. Am J Phys Med Rehabil 86:50-56. https://doi.org/10.1097/PHM.0b013 e31802b8da4

Forth KE, Layne CS (2008) Neuromuscular responses to mechanical foot stimulation: The influence of loading and postural context. Aviat Sp Environ Med 79:844-851. https://doi.org/10.3357/ ASEM.2176.2008

Fransson P, a, Gomez S, Patel M, Johansson L, (2007) Changes in multi-segmented body movements and EMG activity while standing on firm and foam support surfaces. Eur J Appl Physiol 101:81-89. https://doi.org/10.1007/s00421-007-0476-x

Hatton AL, Dixon J, Martin D, Rome K (2009) The effect of textured surfaces on postural stability and lower limb muscle activity. J Electromyogr Kinesiol 19:957-964. https://doi.org/10.1016/j.jelek in.2008.04.012

Hatton AL, Dixon J, Rome K, Martin D (2011) Standing on textured surfaces: effects on standing balance in healthy older adults. Age Ageing 40:363-368. https://doi.org/10.1093/ageing/afr026

Hatton AL, Dixon J, Rome K et al (2012) Altering gait by way of stimulation of the plantar surface of the foot: the immediate effect of wearing textured insoles in older fallers. J Foot Ankle Res 5:11. https://doi.org/10.1186/1757-1146-5-11

Hlavackova P, Vuillerme N (2012) Do somatosensory conditions from the foot and ankle affect postural responses to plantar-flexor muscles fatigue during bipedal quiet stance? Gait Posture 36:16-19. https://doi.org/10.1016/j.gaitpost.2011.10.361

Horak FB, Nashner LM, Diener HC (1990) Postural strategies associated with somatosensory and vestibular loss. Exp Brain Res 82:167-177. https://doi.org/10.1007/BF00230848

Jančová J (2008) Measuring the balance control system—review. Acta Medica (Hradec Kral 129-137

Janin M, Dupui P (2009) The effects of unilateral medial arch support stimulation on plantar pressure and center of pressure adjustment in young gymnasts. Neurosci Lett 461:245-248. https://doi.org/ $10.1016 /$ j.neulet.2009.06.043

Janin M, Toussaint L (2005) Changes in center of pressure with stimulations vi aanterior orthotic devices. Gait Posture 21:S79. https:// doi.org/10.1016/s0966-6362(05)80259-0

Jeka J, Kiemel T, Creath R et al (2004) Controlling human upright posture: Velocity information is more accurate than position or acceleration. J Neurophysiol 92:2368-2379. https://doi.org/10. 1152/jn.00983.2003

Johnson KO (2001) The roles and functions of cutaneous mechanoreceptors. Curr Opin Neurobiol 11:455-461. https://doi.org/10. 1016/S0959-4388(00)00234-8

Kavounoudias A, Roll R, Roll JP (1998) The plantar sole is a "dynamometric map" for human balance control. NeuroReport 9:3247-3252

Kennedy PM, Inglis JT (2002) Distribution and behaviour of glabrous cutaneous receptors in the human foot sole. J Physiol 538:9951002. https://doi.org/10.1113/jphysiol.2001.013087

Kenny RPW, Atkinson G, Eaves DL et al (2019a) The effects of textured materials on static balance in healthy young and older adults: A systematic review with meta-analysis. Gait Posture 71:79-86

Kenny RPW, Eaves DL, Martin D et al (2019b) The effects of textured insoles on quiet standing balance in four stance types with and without vision. BMC Sports Sci Med Rehabil. https://doi.org/10. 1186/s13102-019-0117-9

Kim JW, Eom GM, Kim CS et al (2010) Sex differences in the postural sway characteristics of young and elderly subjects during quiet 
natural standing. Geriatr Gerontol Int 10:191-198. https://doi.org/ 10.1111/j.1447-0594.2009.00582.x

Kitabayashi T, Demura SI, Kawabata H et al (2011) Comparison of the body-sway characteristics of young adults compared to healthy elderly and elderly with equilibrium disorder. Percept Mot Skills 113:547-556. https://doi.org/10.2466/10.15.26.PMS.113.5. 547-556

Le Clair K, Riach C (1996) Postural stability measures: what to measure and for how long. Clin Biomech (Bristol, Avon). 11(3):176178. https://doi.org/10.1016/0268-0033(95)00027-5 PMID: 11415618.

Li PL, Yick KL, Ng SP, Yip J (2019) Influence of textured indoor footwear on posture stability of older women based on center-ofpressure measurements. Hum Factors 61:1247-1260. https://doi. org/10.1177/0018720819837414

Lord SR, Ward JA (1994) Age-associated differences in sensori-motor function and balance in community dwelling women. Age Ageing 23:452-460. https://doi.org/10.1093/ageing/23.6.452

Lord SR, Clark RD, Webster IW (1991) Postural stability and associated physiological factors in a population of aged persons. Journals Gerontol 46:69-76. https://doi.org/10.1093/geronj/46.3.m69

Losa Iglesias ME, de Bengoa B, Vallejo R, Palacios Peña D (2012) Impact of soft and hard insole density on postural stability in older adults. Geriatr Nurs (Minneap) 33:264-271. https://doi.org/10. 1016/j.gerinurse.2012.01.007

Magnusson M, Enbom H, Johansson R, Pyykkö I (1990) Significance of pressor input from the human feet in anterior-posterior postural control. The effect of hypothermia on vibration-induced bodysway. Acta Otolaryngol 110:182-188. https://doi.org/10.3109/ 00016489009122535

Mancini M, Horak FB (2010) The relevance of clinical balance assessment tools to differentiate balance deficits. Eur J Phys Rehabil Med 46:239-248

Manjarrez E, Rojas-Piloni G, Méndez I, Flores A (2003) Stochastic resonance within the somatosensory system: Effects of noise on evoked field potentials elicited by tactile stimuli. J Neurosci 23:1997-2001. https://doi.org/10.1523/jneurosci.23-06-01997. 2003

Menant JC, Steele JR, Menz HB et al (2008) Optimizing footwear for older people at risk of falls. J Rehabil Res Dev 45:1167-1182. https://doi.org/10.1682/JRRD.2007.10.0168

Mesquita LSDA, De Carvalho FT, Freire LSDA et al (2015) Effects of two exercise protocols on postural balance of elderly women: A randomized controlled trial. BMC Geriatr 15:1-9. https://doi.org/ 10.1186/s12877-015-0059-3

Meyer PF, Oddsson LIE, De Luca CJ (2004) Reduced plantar sensitivity alters postural responses to lateral perturbations of balance. Exp brain Res 157:526-536. https://doi.org/10.1007/ s00221-004-1868-3

Nakamura H, Tsuchida T, Mano Y (2001) The assessment of posture control in the elderly using the displacement of the center of pressure after forward platform translation. J Electromyogr Kinesiol 11:395-403

Nejc S, Jernej R, Loefler S, Kern H (2010) Sensitivity of body sway parameters during quiet standing to manipulation of support surface size. J Sport Sci Med 9:431-438

Nurse MA, Nigg BM (2001) The effect of changes in foot sensation on plantar pressure and muscle activity. Clin Biomech (Bristol, Avon) 16:719-727

Nurse MA, Nigg BM (2001) The effect of changes in foot sensation on plantar pressure and muscle activity. Clin Biomech 16:719-727. https://doi.org/10.1016/S0268-0033(01)00090-0

Nurse M, a, Hulliger M, Wakeling JM, et al (2005) Changing the texture of footwear can alter gait patterns. J Electromyogr Kinesiol 15:496-506. https://doi.org/10.1016/j.jelekin.2004.12.003
Orth D, Davids K, Wheat J et al (2013) The role of textured material in supporting perceptual-motor functions. PLoS ONE 8:e60349. https://doi.org/10.1371/journal.pone.0060349

Overstall PW, Johnson AL, Exton-Smith AN (1978) Instability and falls in the elderly. Age Ageing 7:92-96. https://doi.org/10.1093/ ageing/7.suppl.92

Palazzo F, Caronti A, Lebone P et al (2014) Effects of stimulating surface during static upright posture in the elderly. Somatosens Mot Res 00:1-6. https://doi.org/10.3109/08990220.2014.958217

Palazzo F, Caronti A, Lebone P et al (2015) Effects of stimulating surface during static upright posture in the elderly. Somatosens Mot Res 32:61-66. https://doi.org/10.3109/08990220.2014.958217

Palazzo F, Nardi A, Tancredi V, et al (2019) Effect of textured insoles on postural control during static upright posture following lower limb muscle fatigue. J Sports Med Phys Fitness https://doi.org/10. 23736/S0022-4707.17.08029-X

Palluel E, Nougier V, Olivier I (2008) Do spike insoles enhance postural stability and plantar-surface cutaneous sensitivity in the elderly? Age (Dordr) 30:53-61. https://doi.org/10.1007/ s11357-008-9047-2

Palluel E, Olivier I, Nougier V (2009) The lasting effects of spike insoles on postural control in the elderly. Behav Neurosci 123:1141-1147. https://doi.org/10.1037/a0017115

Pasma JH, Bijlsma AY, Van Der Bij MDW et al (2014) Age-related differences in quality of standing balance using a composite score. Gerontology 60:306-314. https://doi.org/10.1159/000357406

Patel M, Fransson P, a, Lush D, et al (2008) The effects of foam surface properties on standing body movement. Acta Otolaryngol 128:952-960. https://doi.org/10.1080/00016480701827517

Patel M, Fransson P, a, Johansson R, Magnusson M, (2011) Foam posturography: standing on foam is not equivalent to standing with decreased rapidly adapting mechanoreceptive sensation. Exp brain Res 208:519-527. https://doi.org/10.1007/s00221-010-2498-6

Perry SD, McIlroy WE, Maki BE (2000) The role of plantar cutaneous mechanoreceptors in the control of compensatory stepping reactions evoked by unpredictable, multi-directional perturbation. Brain Res 877:401-406

Peterka R (2002) Sensorimotor integration in human postural control. J Neurophysiol 88:1097-1118

Prieto TE, Myklebust JB, Hoffmann RG et al (1996) Measures of postural steadiness: Differences between healthy young and elderly adults. IEEE Trans Biomed Eng 43:956-966. https://doi.org/10. $1109 / 10.532130$

Priplata AA, Niemi JB, Harry JD et al (2003) Vibrating insoles and balance control in elderly people. Lancet 362:1123-1124. https:// doi.org/10.1016/S0140-6736(03)14470-4

Qiu F, Cole MH, Davids KW et al (2012) Enhanced somatosensory information decreases postural sway in older people. Gait Posture 35:630-635. https://doi.org/10.1016/j.gaitpost.2011.12.013

$\mathrm{Qu} X$ (2015) Impacts of different types of insoles on postural stability in older adults. Appl Ergon 46:38-43. https://doi.org/10.1016/j. apergo.2014.06.005

Raymakers JA, Samson MM, Verhaar HJJ (2005) The assessment of body sway and the choice of the stability parameter(s). Gait Posture 21:48-58. https://doi.org/10.1016/j.gaitpost.2003.11.006

Rogers MW, Mille ML (2003) Lateral stability and falls in older people. Exerc Sport Sci Rev 31:182-187. https://doi.org/10.1097/ 00003677-200310000-00005

Røgind H, Lykkegaard JJ, Bliddal H, Danneskiold-Samsøe B (2003) Postural sway in normal subjects aged 20-70 years. Clin Physiol Funct Imaging 23:171-176. https://doi.org/10.1046/j.1475-097X. 2003.00492.x

Shumway-Cook A, Baldwin M, Polissar NL, Gruber W (1997) Predicting the probability for falls in community-dwelling older adults. Phys Ther 77:812-819. https://doi.org/10.1093/ptj/77.8.812 
Strzalkowski NDJ, Ali RA, Bent LR (2017) The firing characteristics of foot sole cutaneous mechanoreceptor afferents in response to vibration stimuli. J Neurophysiol 118:1931-1942. https://doi.org/ 10.1152/jn.00647.2016

Teasdale N, Stelmach GE, Breunig A (1991) Postural sway characteristics of the elderly under normal and altered visual and support surface conditions. J Gerontol 46:238-244. https://doi.org/10. 1093/geronj/46.6.B238

Tinetti ME, Speechley M, Ginter SF (1988) Risk Factors for falls among elderly persons living in the community. N Engl J Med 319:1701-1707. https://doi.org/10.1056/NEJM198812293192604

Vieira T, Botter A, Gastaldi L et al (2017) Textured insoles affect the plantar pressure distribution while elite rowers perform on an indoor rowing machine. PLoS ONE 12:1-14. https://doi.org/10. 1371/journal.pone.0187202

Viseux F, Barbier F, Villeneuve P et al (2018) Low additional thickness under the toes could change upright balance of healthy subjects. Neurophysiol Clin 48:397-400. https://doi.org/10.1016/j.neucli. 2018.08.001

Viseux F, Lemaire A, Barbier F et al (2019) How can the stimulation of plantar cutaneous receptors improve postural control? Review and clinical commentary. Neurophysiol Clin 49:263-268

Vrancken AMPM, Allum JHJ, Peller M et al (2005) Effect of bilateral subthalamic nucleus stimulation on balance and finger control in Parkinson's disease. J Neurol 252:1487-1494. https://doi.org/10. 1007/s00415-005-0896-7
Wang Y, Watanabe K, Chen L (2016) Effect of plantar cutaneous inputs on center of pressure during quiet stance in older adults. J Exerc Sci Fit 14:24-28. https://doi.org/10.1016/j.jesf.2016.02.001

Watanabe I, Okubo J, Medical T (1981) The role of the plantar mechanoreceptor. Annal New York Acad Sci 0:855-864

Wilson ML, Rome K, Hodgson D, Ball P (2008) Effect of textured foot orthotics on static and dynamic postural stability in middle-aged females. Gait Posture 27:36-42. https://doi.org/10.1016/j.gaitp ost.2006.12.006

Winter DA (1995) Human balance and posture control during standing and walking. Gait Posture 3:193-214

Winter DA, Prince F, Frank JS et al (1996) Unified theory regarding $\mathrm{A} / \mathrm{P}$ and $\mathrm{M} / \mathrm{L}$ balance in quiet stance. $\mathrm{J}$ Neurophysiol 75:2334-2343

Zehr EP, Nakajima T, Barss T et al (2014) Cutaneous stimulation of discrete regions of the sole during locomotion produces "sensory steering" of the foot. BMC Sports Sci Med Rehabil 6:33. https:// doi.org/10.1186/2052-1847-6-33

Publisher's Note Springer Nature remains neutral with regard to jurisdictional claims in published maps and institutional affiliations. 